\title{
GEOCHEMISTRY AND PETROLOGY OF FELSIC AND MAFIC SUITES RELATED TO THE PALEOPROTEROZOIC TRANSAMAZONIAN OROGENY IN MINAS GERAIS, BRAZIL
}

\section{JOEL JEAN GABRIEL QUÉMÉNEUR AND CARLOS MAURICIO NOCE}

\begin{abstract}
Paleoproterozoic ( $c a$. 2.0-2.1 Ga) intrusive rocks exposed along the southern border of the São Francisco Craton have been divided into three suites: granite suite, TTG (tonalite-trondhjemite-granodiorite) suite, and gabro-diorite suite. The granite suite comprises two distinct groups of plutons, one composed of highly differentiated peraluminous granites, and the other including less evolved metaluminous to peraluminous high-K granites. It is suggested that granitic plutons are not derived from a single magma source, probably due to their association to more than one stage of the orogen evolution. TTG and gabro-diorite suites follow a calc-alkaline trend, and may constitute a single large suite originated from mantle-derived magmas at a plate margin setting. However, chemical data of some granodioritic plutons of the TTG suite indicates contribution of crust-derived material.
\end{abstract}

Keywords: geochemistry, petrology, felsic suites, mafic suites, Paleoproterozoic

GEOLOGICAL SETTING Several granitoid and mafic intrusions exposed along the southern border of the São Francisco Craton in Minas Gerais have been dated at $c a$. 2.0-2.1 Ga (Teixeira 1985 Quéméneur and Vidal 1989, Heilbron et al. 1989, Choudhuri et al. 1992, Teixeira et al. 1998, Avila et al. 1998, Noce et al. 1998). These intrusions are part of a magmatic arc related to the Transamazonian Orogeny, and are intrusive into an Archean crust composed of TTG gneiss, granite-gneiss, migmatite, granulite, and greenstone belt remnants (Fig. 1)

Metamorphic grade of Archean rocks increases westward, from amphibolite facies in the São João del Rei-Lavras area to granulite facies in the Lavras-Carmópolis area. Granulitic rocks comprise charnockite, enderbite, charnockite gneiss, mafic granulite, and spinelbearing ultramafic rock. Charnockites are probably of magmatic origin and yielded a Rb-Sr whole-rock isochron of $2660 \pm 30 \mathrm{Ma}$ (Quéméneur 1995). Migmatites of granitic composition predominates to the north of the granulitic rocks, and are included in the Campo Belo Complex.
The migmatization event was dated at $2839 \pm 17 \mathrm{Ma}$ (U-Pb age, Teixeira et al. 1998).

Greenstone successions mainly composed of mafic- to ultramafic rocks of tholeiitic to komatiitic composition make up a disrupted belt that extends south of the Quadrilátero Ferrífero to the west of Lavras (Barbacena Greenstone Belt, Pires et al. 1990).

THE TRANSAMAZONIAN MAGMATIC ARC The magmatic arc was first defined by Quéméneur et al. (1994). It extends from more than $250 \mathrm{Km}$ from east to west comprising roughly aligned granitoid and mafic bodies. This paper will focus on the central part of the belt, where the intrusive rocks have been divided into three suites: granite suite, TTG (tonalite-trondhjemite-granodiorite) suite, and gabro-diorite suite.

Chemical analysis presented hereafter were carried out at the École de Mines de Saint Etienne (France) by using a X-ray fluorescence and ICP-MS.
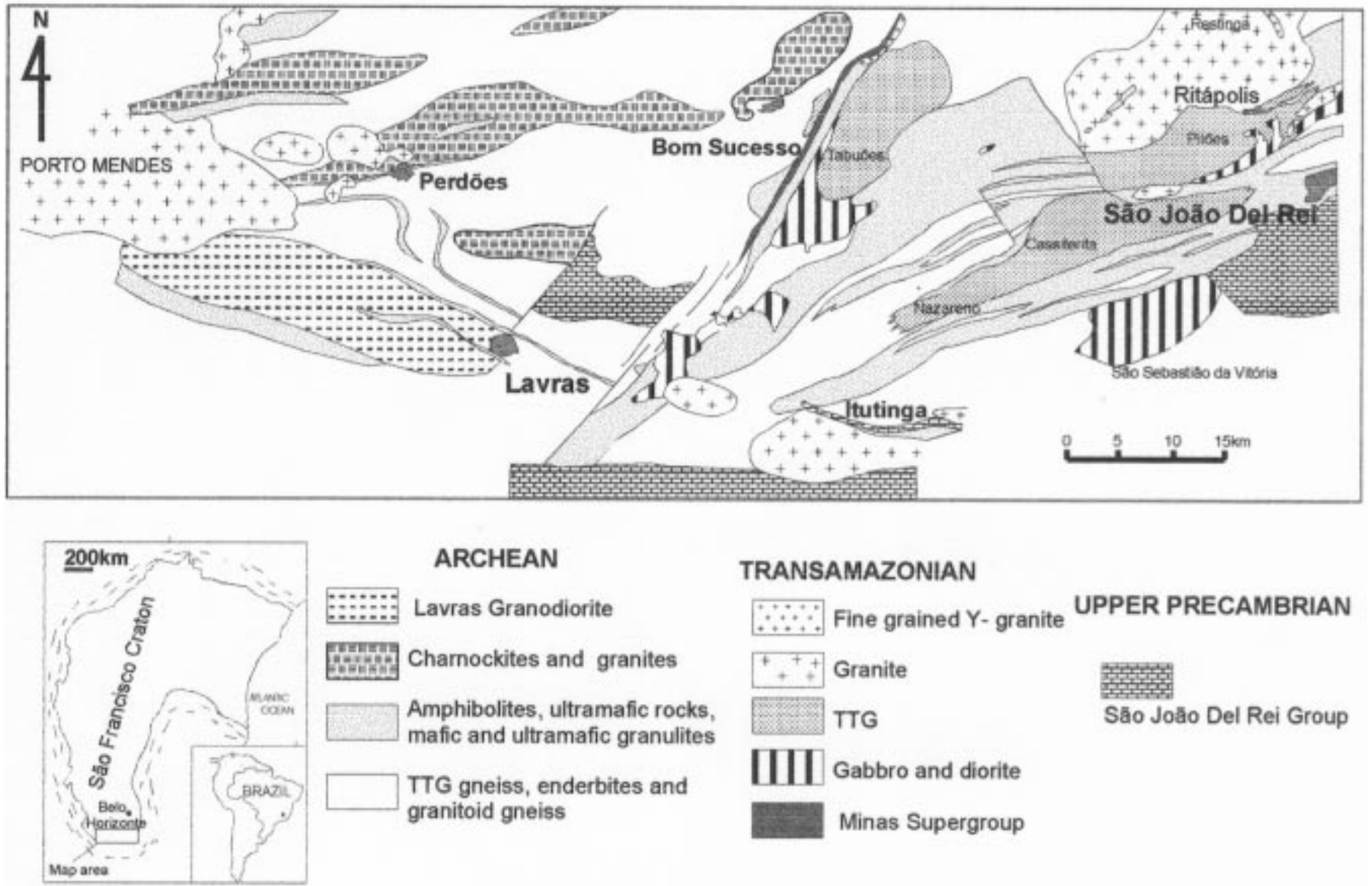

\section{ARCHEAN}

Lavras Granodiorite

Charnockites and granites

Amphibolites, ultramafic rocks,

mafic and ultramafic granulites

TTG gneiss, enderbites and granitoid gneiss

\section{TRANSAMAZONIAN}

$\because \because \because$ Fine grained $\mathrm{Y}$-granite UPPER PRECAMBRIAN

+++ Granite
TTG

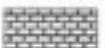

Săo Joăo Del Rei Group

Gabbro and diorite

Minas Supergroup

Figure 1 - Geologic map of southern border of the São Francisco craton displaying Transamazonian intrusive bodies and the Archean basement 
Granite suite It comprises two distinct groups of plutons. Ritápolis, Itutinga and Perdões intrusions are highly differentiated peraluminous granites, while the Porto Mendes massif is a less evolved metaluminous to peraluminous high-K granite (Table 1).

RITÁPOLIS MASSIF Granitic rocks of Ritápolis have been studied by many authors, including Guimarães and Guedes (1944), Ebert (1956), Quéméneur and Baraud (1983), Porto Jr. (1988), among others. The Ritápolis massif is a large $\left(25 \times 13.5 \mathrm{~km}, 250 \mathrm{~km}^{2}\right)$ ovoidshaped body intrusive into Archean greenstone belt rocks, and associated to a surrounding pegmatite field that includes lithium-tintantalum-bearing pegmatites. Its southern contact with the Pilões granodiorite is rather irregular and many enclaves of this rock are found within the Ritápolis massif, even in its central portion.

The Ritápolis granite displays an isotropic texture except for its southern portion where it is affected by the north-verging São João del Rei-Nazareno shear zone, developing an E-W foliation. Despite its size, the massif is quite homogeneous and composed of a leucocratic medium-grained granite, porphyritic at some places. The rock-forming minerals are K-feldspar (30-40\%), comprising large $(4-8 \mathrm{~mm})$ subidiomorphic mesoperthite crystals and small microcline crystals, quartz (30-40\%), plagioclase (15-25\%, $\left.\mathrm{An}_{2}-\mathrm{An}_{12}\right) 2-6 \mathrm{~mm}$ in size, and green biotite $(3-4 \%)$ that can be altered to muscovite. Accessory minerals are apatite, epidote, allanite, sphene, ilmenite and zircon. The Ritápolis granite plots on the monzogranite field of the Streckeisen's diagram.

The chemical analysis plot on the granite and adamellite fields of the Debon and Lefort's (1983) diagram, and on the peraluminous field of the Maniar and Picolli's (1989) diagram based on Shand's index. The Ritápolis granite is a highly fractionated S-type granite, with high contents of $\mathrm{Si}, \mathrm{Rb}$ and $\mathrm{U}$, and low contents of $\mathrm{Fe}, \mathrm{Ti}, \mathrm{Mg}, \mathrm{Ca}, \mathrm{Ba}, \mathrm{Li}$ (24 ppm) and V (3 ppm). Rocks from the western portion of the massif are enriched in $\mathrm{Ti}, \mathrm{Zr}, \mathrm{Ba}, \mathrm{U}$, Th and REE, compared to the ones from the eastern portion, what may imply in the presence of two distinct intrusions.

RESTINGA GRANITE (Y-RICH GRANITE) It is a small body $(6.5 \times 1.2 \mathrm{~km})$ located at the northeastern border of the Ritápolis Massif. It is a homogeneous fine-grained $(1-2 \mathrm{~mm})$ mesocratic granite, composed by K-feldspar (40-45\%), quartz (30-35\%), oligoclase (20\%) and minor secondary albite, and biotite (6-7\%). REE-, Y- and Zr-rich accessory minerals like allanite, monazite, xenotime, and zircon are always present.

The Restinga granite chemical composition is in marked contrast to the Ritápolis granite composition. The Restinga granite is less fractionated and displays an alkaline trend. It contains high values of both incompatible elements like $\mathrm{Rb}, \mathrm{U}$ and $\mathrm{Th}$, and compatible elements like $\mathrm{Ba}, \mathrm{Zr}, \mathrm{V}$ (average $16 \mathrm{ppm}$ ) and $\mathrm{Li}$ (average $65 \mathrm{ppm}$ ). High Y content (average $357 \mathrm{ppm}$ ) is the most characteristic feature of this granite. The alkaline trend is indicated by the $\mathrm{Y}$ and also by the high REE contents. No radiometric ages are available for the Restinga granite, and its field relations with the Ritápolis granite are not observed. Thus, its inclusion into the Transamazonian arc is still uncertain.

ITUTINGA GRANITE This pluton was deformed during the Neoproterozoic Brasiliano Orogeny. An oblique NE verging thrusting system, associated to the São João del Rei-Nazareno shear zone, affected both the metasediments of the Andrelândia Group and its basement, represented by the Itutinga granite and Archean gneiss. The granite is partially mylonitized and displays an E-W foliation. Mylonitic rocks are composed of a quartz-microcline matrix displaying porphyroclasts of microcline, mesoperthite and plagioclase, plus small idiomorphic biotite crystals altered to chlorite. At less-deformed zones the granite is porphyritic with large $\mathrm{K}$-feldspar phenocrysts and a coarse-grained (5 mm) matrix.

Its chemical composition is similar to the Ritápolis granite composition. The Itutinga pluton is a fractionated peraluminous granite containing low $\mathrm{Fe}, \mathrm{Mg}, \mathrm{Ca}, \mathrm{Ti}, \mathrm{Ba}$ and $\mathrm{REE}$, high $\mathrm{U}$ contents, and high $\mathrm{Na} / \mathrm{Ca}, \mathrm{Rb} / \mathrm{Sr}$ and $\mathrm{Pb} / \mathrm{Zn}$ values.

PORTO MENDES MASSIF AND SATELLITE BODIES The Porto Mendes massif was first identified during a 1:250,000 scale mapping project (Projeto Sapucaí, Cavalcante et al. 1979). It is the largest
Transamazonian intrusion in the area $(35 \times 20 \mathrm{~km})$ and is associated to many satellite bodies exposed at the vicinities of the massif's northeastern border. Those are the Perdões granite, Serrinha granite, Toscano de Brito granite, and Bom Jardim granodiorite.

The main body is composed of a light-gray medium- to coarsegrained $(4-10 \mathrm{~mm})$ granite, locally porphyritic. Magmatic banding is often found at the outer parts of the massif. Its mineralogical composition falls on the monzogranite field of QAP diagram. Plagioclase is often altered to saussurite and biotite to chlorite. Accessory minerals are secondary epidote, apatite, allanite, opaque minerals and zircon. Chemical composition reveals that the Porto Mendes granite is poorly fractionated, metaluminous to peraluminous, with high $\mathrm{Fe}, \mathrm{Mg}, \mathrm{Ca}, \mathrm{P}, \mathrm{Ti}, \mathrm{Zr}, \mathrm{Ba}$ and REE, and low $\mathrm{U}$ contents. High $\mathrm{Rb}, \mathrm{REE}$ and $\mathrm{Zr}$ contents suggest a poorly defined alkaline trend.

The satellite bodies can be divided into two groups; one comprises granites with identical chemical composition as the main body, like the Serrinha granite and the other display a more fractionated character, like the Perdões granite. The Perdões granite is fine-grained and micapoor. Its chemical composition is similar to more evolved granites like Ritápolis and Itutinga, except for higher $\mathrm{Ba}$ and lower $\mathrm{Rb}$ contents. Low $\mathrm{Rb}$ content may indicates that it is not a product of Porto Mendes magma fractionation. The Bom Jardim granodiorite is probably a distinct intrusion because its mineralogical and chemical composition is more akin to that of the TTG suite (see next section). It contains high $\mathrm{TiO}_{2}(0.76 \%), \mathrm{Ba}(2284 \mathrm{ppm}), \mathrm{Zr}(548 \mathrm{ppm})$ and $\mathrm{REE}(291 \mathrm{ppm} \mathrm{Ce})$

Table 1 - Selected chemical data of the granite suite. Major elements expressed as $w t \%$, trace elements expressed as ppm

\begin{tabular}{|l|c|c|c|c|c|c|}
\hline & $\begin{array}{c}\text { Ritápolis } \\
\text { (east) }\end{array}$ & $\begin{array}{c}\text { Ritápolis } \\
\text { (west) }\end{array}$ & Restinga & Itutinga & $\begin{array}{c}\text { P. } \\
\text { Mendes }\end{array}$ & Perdões \\
\hline $\mathrm{FeO}$ & 1.51 & 1.51 & 2.21 & 1.46 & 2.19 & 1.30 \\
\hline $\mathrm{TiO}_{2}$ & 0.09 & 0.13 & 0.26 & 0.12 & 0.32 & 0.12 \\
\hline $\mathrm{MgO}$ & 0.27 & 0.26 & 0.37 & 0.19 & 0.53 & 0.22 \\
\hline $\mathrm{Rb}$ & 274 & 254 & 358 & 207 & 226 & 166 \\
\hline $\mathrm{Ba}$ & 290 & 361 & 847 & 218 & 1156 & 643 \\
\hline $\mathrm{Zr}$ & 101 & 145 & 207 & 114 & 236 & 128 \\
\hline $\mathrm{U}$ & 28 & 77 & 23 & 16 & 6.7 & 19.1 \\
\hline $\mathrm{Ce}$ & 55 & 126 & 174 & 88 & 159 & 39 \\
\hline $\mathrm{Na} / \mathrm{Ca}$ & 11.0 & 8.4 & 6.4 & 7.8 & 5.1 & 7.61 \\
\hline $\mathrm{Rb} / \mathrm{Sr}$ & 5.56 & 4.55 & 3.85 & 4.35 & 1.27 & 1.23 \\
\hline $\mathrm{Zn} / \mathrm{Pb}$ & 0.68 & 0.46 & 1.46 & 0.52 & 0.78 & 0.48 \\
\hline
\end{tabular}

contents.

TTG (tonalite-trondhjemite-granodiorite)

suite

TABUÕES TONALITE This body covers $c a .70 \mathrm{~km}^{2}$, composed of a light-gray fine- to medium-grained tonalite. Magmatic planar structure can be observed at many outcrops, superimposed by a weakly developed $\mathrm{E}-\mathrm{W}$ tectonic foliation. The rock-forming minerals are oligoclase $\left(\mathrm{An}_{22}-\mathrm{An}_{26}, 50-60 \%\right)$, quartz (25-30\%), microcline (10\%), and biotite (5-8\%). Accessory minerals are apatite, epidote, sphene, allanite, and zircon. It is noteworthy the relative abundance of rounded zircon crystals and allanite with a rim of epidote.

The Tabuões intrusion has a tonalite to trondhjemite chemical composition (Na-Ab-Or diagram after O'Connor 1965, see table 2), with $\mathrm{Na} / \mathrm{K}>3.5$ and $2.5<\mathrm{Na} / \mathrm{Ca}<3.5$. $\mathrm{TiO}_{2}(0.20-0.48 \%)$ and $\mathrm{Ba}(670-$ $1170 \mathrm{ppm}$ ) contents show an almost linear positive correlation. At the northern border of the pluton lies a small granite stock with a chemical composition that resembles the one of the Restinga granite, albeit its lower Y content. These granites are probably not associated to any of the large surrounding plutons, i.e., the Ritápolis granite and Tabuões tonalite.

The Tabuões tonalite is the only Transamazonian intrusion with a well-defined metamorphic aureole, especially along its eastern border where it is in contact with the Minas Supergroup. Contact metamorphism is evidenced by crystallization of garnet, sillimanite and staurolite in quartz-biotite schists. Itabirites preserve their primary banded texture, but quartz and iron oxides are replaced by grunnerite. CASSITERITA AND PILÕES MASSIFS These two parallel bodies cover together $c a .300 \mathrm{~km}^{2}(45 \times 10 \mathrm{~km})$, and are separated by the Caburu shear zone. The Pilões granodiorite is exposed north of the Caburu shear zone. Veins of the Ritápolis granite cut the Pilões granodiorite along the contact between the two bodies. The latter 
displays a Rb enrichment that suggests K-metassomatism during intrusion of the Ritápolis granite.

The Cassiterita pluton is limited by the Caburu shear zone to the north, and the São João del Rei-Nazareno shear zone to the south. Where deformation is more intense, like the central portion of the pluton, the rock is medium-grained biotite gneiss. However, it differs from the adjacent Archean TTG gneiss because the latter always displays a characteristic banded texture. A fine-grained (1-3 mm) granodiorite predominates in less-deformed zones like the northeastern margin. The intrusion is predominantly composed of granodiorite and tonalite, cut by several trondhjemitic veins. Its easternmost portion displays a trondhjemitic- to tonalitic composition (Avila 1992). Rockforming minerals are plagioclase (40-50\%), quartz (30-35\%), microcline (8-15\%), and biotite (6-10\%). The most common accessory minerals are sphene, ilmenite, apatite, secondary epidote, allanite and zircon. Granodioritic rocks are rich in $\mathrm{Ti}, \mathrm{Ba}, \mathrm{Zr}$ and REE. Their mantelic character is indicated by high $\mathrm{Zn} / \mathrm{Pb}$ values (average 3.49). Trondhjemitic rocks are more leucocratic and poorer in $\mathrm{K}, \mathrm{Ti}, \mathrm{Ba}, \mathrm{Zr}$ and REE. $\mathrm{Zn} / \mathrm{Pb}$ values are also slightly lower (3.06) when compared to granodiorites. Chemical compositions of Cassiterita and Pilões intrusions are very similar, suggesting that they are co-genetic (see table 2).

Gabro-diorite suite It includes four gabro- to diorite intrusions that are distinguished from the TTG suite by their high amphibole content. However, both suites follow a calc-alkaline trend in the Irvine and Baragar's (1971) AFM diagram, and may constitute a single large suite.

SÃO SEBASTIÃO DA VITÓRIA MASSIF This is the largest gabrodiorite intrusion covering $c a .60 \mathrm{~km}^{2}$. Deformation along the São João del Rei-Nazareno shear zone resulted in numerous zones of schist cutting the massif. The same event was probably responsible for widespread chlorite and epidote alteration of gabros and diorites. Aplite veins of trondhjemitic composition that may be related to the Cassiterita pluton also cut the massif.

IBITUTINGA DIORITE This intrusion was named as Ibitutinga diorite by Ávila (1992), who lately proposed its subdivision into two bodies, Brumado and Gloria diorites (Ávila et al. 1998). In fact, outcrops of the Ritápolis granite and the Pilões granodiorite separate the two sides of the massif, but they could represent a single body affected by younger granitic intrusions. Alternatively, dioritic rocks may represent more mafic facies of the Pilões granodiorite.

IBITURUNA MARTINS AND ROSÁRIO MASSIFS The Ibituruna massif is made of a greenish gray rock, medium-grained (3-6 $\mathrm{mm}$ ) and amphibole-rich. Its composition varies from diorite to tonalite, and it may represent an extension of the Tabuões tonalite. Dioritic rocks are composed of plagioclase (44-55\%) intensively altered to epidote, hornblende (10-20\%), quartz (5-15\%), microcline (5-10\%), and biotite $(2-4 \%)$. Accessory minerals are sphene, ilmenite, epidote, apatite, allanite, and pyrrhotite. Southern of the Ibituruna massif lies a small body of gabro (Martins gabro) that may be part of the same intrusion.

The Rosário diorite is highly deformed and mylonitic at its southern half, due to its location within the Serra do Bonsucesso shear zone. It contains significant amounts of sulfide minerals like pyrrhotite and

Table 2: Selected chemical data of the TTG and gabro-diorite suites. Major elements expressed as wt\%, trace elements expressed as ppm

\begin{tabular}{|l|c|c|c|c|c|}
\hline & Pilões & Cassiterita & Tabuões & Ibituruna & Martins \\
\hline $\mathrm{Fe}_{2} \mathrm{O}_{3}$ & 3.60 & 3.61 & 3.18 & 5.56 & 8.58 \\
\hline $\mathrm{TiO}_{2}$ & 0.68 & 0.62 & 0.40 & 0.57 & 0.66 \\
\hline $\mathrm{MgO}$ & 1.05 & 1.25 & 1.12 & 2.41 & 5.86 \\
\hline $\mathrm{Rb}$ & 119 & 68 & 44 & 60 & 29 \\
\hline $\mathrm{Ba}$ & 1195 & 1140 & 640 & 1104 & 516 \\
\hline $\mathrm{Zr}$ & 234 & 175 & 175 & 164 & 94 \\
\hline $\mathrm{Ce}$ & 85 & 79 & 98 & 98 & 63 \\
\hline $\mathrm{Na} / \mathrm{Ca}$ & 3.05 & 2.61 & 2.89 & 1.81 & 0.813 \\
\hline $\mathrm{Sr} / \mathrm{Rb}$ & 4.20 & 6.31 & 13 & 12.8 & 20 \\
\hline $\mathrm{Zn} / \mathrm{Pb}$ & 3.5 & 3.49 & 4.01 & 4.86 & 12.5 \\
\hline
\end{tabular}

chalcopyrite.

DISCUSSION AND CONCLUSION The three suites plot separately on a $\mathrm{SiO}_{2} / \mathrm{Al}_{2} \mathrm{O}_{3}$ versus $\mathrm{Log} \mathrm{Zn} / \mathrm{Pb}$ diagram (Fig. 2), and also on a $\mathrm{Ba}$ versus $\mathrm{Zr}$ diagram. In the latter the granodioritic rocks plot apart from other rocks of the TTG suite because of their high Ba and $\mathrm{Zr}$ contents. In Ti versus $\mathrm{Mg}$ and $\mathrm{TiO}_{2}$ versus $\mathrm{Zr}$ diagrams (Fig. 3) all rocks of the TTG suite plot together. In $\mathrm{MgO}$ versus $\mathrm{TiO}_{2}$ and $\mathrm{TiO}_{2}$ versus $\mathrm{Zr}$ diagrams chemical data of the granite suite display a linear trend, suggesting a differentiation process of a magma with a composition similar to the Porto Mendes granite. However, based on other diagrams its is more likely that the linear array reflects the degree of fractionation of distinct magmas. In Ce versus $\mathrm{Zr}, \mathrm{Log}(\mathrm{Rb} / \mathrm{Sr})$ versus $\mathrm{Ba}$ (Fig. 4), and $\mathrm{Zr}$ versus $(\mathrm{La}+\mathrm{Ce})$ diagrams, it can be distinguished two separate fields, one of Porto Mendes and Perdões granites, and the other of Ritápolis, Itutinga and Restinga granites. Isotopic data (Noce et al. 2000) had already indicated the presence of distinct magma sources of rocks of the granite suite.

Intrusion ages of the TTG suite are around 2.12-2.16 Ga (Noce et al. 1998, Ávila et al. 1998), while Sm-Nd T ${ }_{\mathrm{PM}}$ ages range from 2.27 to $2.43 \mathrm{Ma}$ (Noce et al. 2000). It is proposed that this suite is derived from mixing of varied proportions of Paleoproterozoic mantelic material and Archean crust material (Noce et al. 2000). The granite suite displays older Sm-Nd $\mathrm{T}_{\mathrm{DM}}$ ages; 2.66-2.77 Ma for Ritápolis and Itutinga granites, and ca. 3.0 Ga for Porto Mendes and Perdões

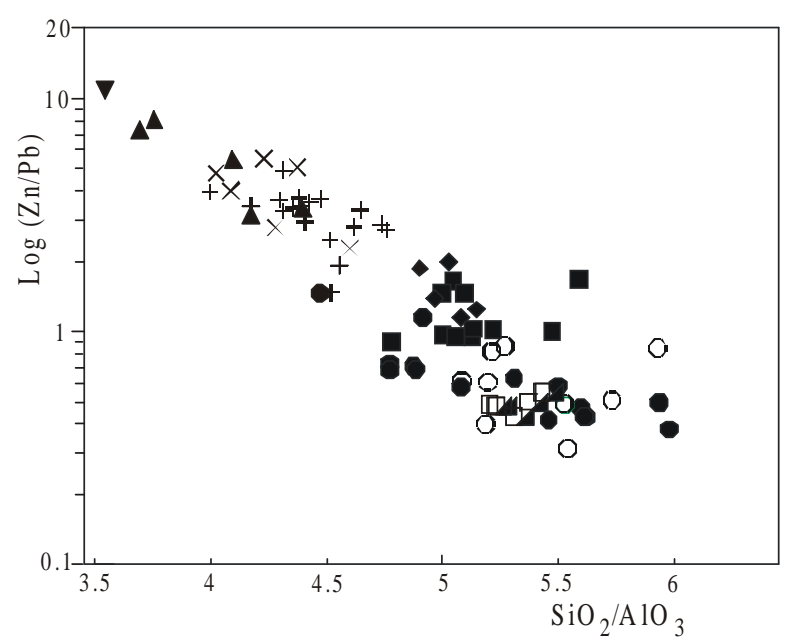

Figure 2- $\mathrm{SiO}_{2} / \mathrm{Al}_{2} \mathrm{O}_{3}$ versus $\mathrm{Log} \mathrm{Zn} / \mathrm{Pb}$ diagram. Granite suite: Itutinga (open circle), Ritápolis (filled circle), Restinga (filled diamond), Porto Mendes (filled square), Perdões (half-filled square). TTG and gabro-diorite suites: Tabuões tonalite $(X)$, Cassiterita and Pilões granodiorites (+), Ibituruna diorite (filled triangle), Martins gabro (updow filled triangle).

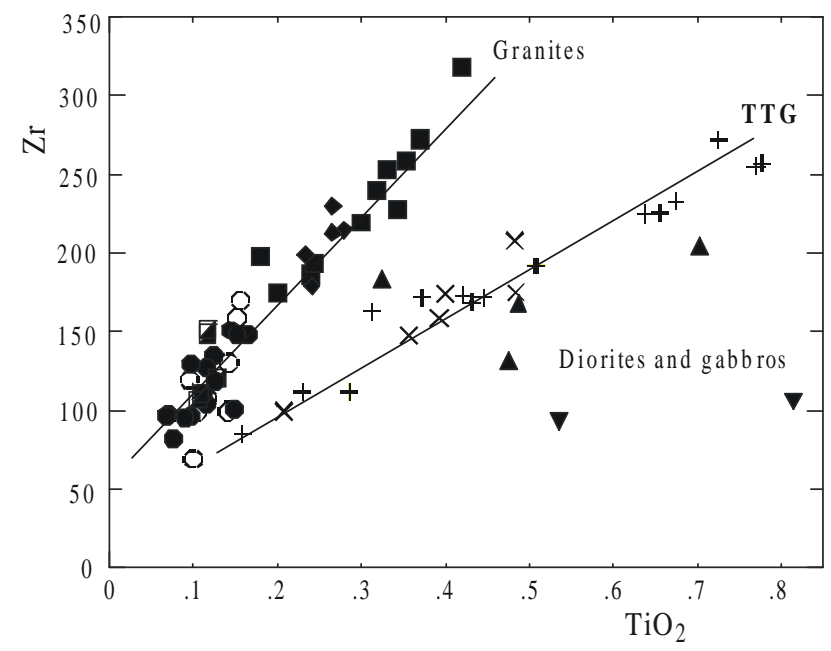

Figure 3 - $\mathrm{TiO}_{2}$ versus $\mathrm{Zr}$ diagram (symbols as in Fig. 2). 


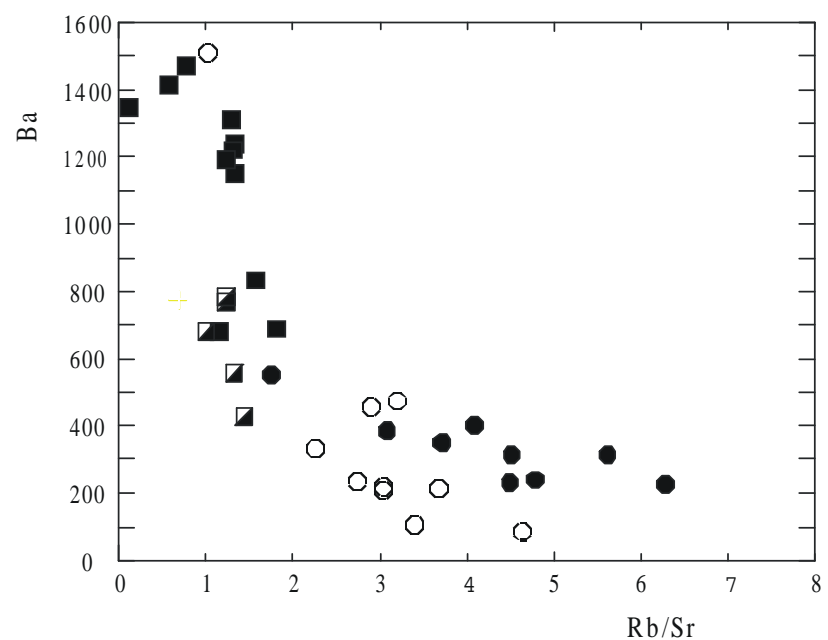

Figure 4 - Log (Rb/Sr) versus Ba diagram (symbols as in Fig. 2). granites. These values reflect the age of the Archean crust surrounding the granitic intrusions, as demonstrated by the Mesoarchean ages of the Campo Belo Complex adjacent to the Porto Mendes massif (Teixeira et al. 1998).

The three suites are probably associated to distinct evolutionary stages of the Tranzamazonian Orogeny. TTG and Gabro-Diorite suites may have originated from mantle-derived magmas at a plate margin setting. Some intrusions like the Cassiterita and Pilões massifs are relatively rich in $\mathrm{K}, \mathrm{Ba}$ and $\mathrm{Zr}$, suggesting contribution of crustderived material. The granite suite comprises less-fractionated rocks like the Porto Mendes granite, and highly fractionated S-type granites like the Ritápolis massif. It is not clear if they all were originated at the same tectonic stage, as precise magmatic ages are not available. In the tectonic discrimination diagrams of Pearce et al. (1984), Porto Mendes granite plots on the volcanic-arc field, while the majority of data of Ritápolis, Itutinga and Perdões granites plot on the within-plate field.

Acknowledgements To FAPEMIG (Project CEX-2157/96) for financial support and two anonymous referees of RBG for their suggestions to the original.

\section{References}

Ávila C.A. 1992. Geologia, petrografia e geoquímica das rochas intrusivas precambrianas (unidade metadiorítica Ibitutinga e unidade meta trondhjemítica Caburu) nas rochas do Greenstone belt Barbacena São João del Rei, Minas Gerais. Instituto de Geociências, Universidade Federal do Rio de Janeiro, Rio de Janeiro, Dissertação de Mestrado, $268 \mathrm{p}$

Ávila C.A., Valença J.G., Pinheiro Jr.V., Rostirolla S., Soares P.C. 1998. Idades ${ }^{207} \mathrm{~Pb} /{ }^{206} \mathrm{~Pb}$ em zircões de corpos metaplutônicos da região de São João del Rei, borda sul do Cráton do São Francisco, Minas Gerais. In: SBG, Congresso Brasileiro de Geologia, 40, Belo Horizonte, Anais, p. 34

Cavalcante J.C. Cunha L.C. Chieregati C.A., Yamamoto K., Drumond J.B. V. Rocha J.M. Coutinho M.G.M. 1979. Projeto Sapucaí, relatório final, DNPM- CPRM, São Paulo

Chouduri A., Costa A.P., Schrank A., Szabo G.A.J., Yer S.S. 1992. The Quilombo Granite in the Morro do Ferro Greenstone Belt, SW Minas Gerais and the character of the transamazonian event. Revista Escola de Minas, 45:152-154

Debon F. and Lefort P. 1983. A chemical mineralogical classification of common plutonic rocks and associations. Transactions of the Royal Society of Edingburg, Earth Sciences, 73:135-149

Ebert H. 1956. Relatório de atividades, Relatório anual do Diretor ano1956, Rio de Janeiro, DNPM-CGM, p. 97-107

Guimarães D. and Guedes S.W. 1944. Nota preliminar sobre a região estanifera de São João del Rei, Minas Gerais, DNPM-CPRM, Avulso 58, p. 13-26

Heilbron M., Gonçalves M.L., Teixeira W., Trouw R.A.J., Padilha A.V., Kawashita K. 1989 Geocronologia da região entre Lavras, São João del Rei, Lima Duarte e Caxambu. Geocronologia da região entre Lavras, São João del Rei, Lim
Anais da Acadademia Brasileira de Ciências, 6 (2):177-199

Irvine T. N. and Baragar W.R.A. 1971. A guide to the chemical classification of the common volcanic rocks. Canadian Journal of Earth Sciences, 8:523-548

Maniard P.D. and Picolli P.M. 1989. Tectonic discrimination of granitoids. Geological Society of America Bulletin, 101:635-643

Noce C.M., Machado N., Teixeira W. 1998. U-Pb geochronology of gneisses and granitoids in the Quadrilátero Ferrífero (southern São Francisco craton): age constraints for Archean and Paleoproterozoic magmatism and metamorphism. Revista Brasileira de Geociências, 28 (1): 95-102

Noce C.M., Teixeira W., Quéméneur J.J.G., Martins V.T.S., Bolzachini, E. 2000. Isotopic signature of Paleoproterozoic granitoids from the southern São Francisco Craton and implications for the evolution of the Transamazonian Orogeny. Journal of South America Earth Sciences (in press)
O'Connor J.T. 1965. A classifications of quartz-rich igeneous rocks based on feldspar ratios. U.S. Geological Survey Professional Paper, 525-B:79-84

Pearce J.A., Harris N.B.W., Tindle A.G. 1984. Trace element discrimination diagrams for tectonic interpretation of granitic rocks. Journal of Petrology, 25:956-983.

Pires F.R.M., Ribeiro A., Barbosa M.I.M. 1990. Distribuição do Greenstone Belt Barbacen na região de São João del Rei, Minas Gerais. In: SBG, Congresso Brasileiro de Geologia, 36, Natal, Anais, 5:2941-2951

Porto Jr. R. 1988. Petrografia, relações temporais e aspectos geoquímicos das rochas do Grupo Barbacena e do Granito de Santa Rita, na região de Ritápolis e Coronel Xrupo Barbacena e do Granito de Santa Rita, na região de Ritápolis e Coronel Xavier Xaves,

Quéméneur, J.J.G. 1995. Os magmatismos de idade Arqueana e Transamazônica na região Campos das Vertentes, sul do Cráton do São Francisco, com base em geoquímica e geocronologia. Instituto de Geociências, Universidade Federal de Minas Gerais, Belo Horizonte, Tese de Professor Titular, $79 \mathrm{p}$

Quéméneur J.J.G. and Baraud R. 1983. Estrutura do Embasamento Arqueano e geologia econômica da área pegmatítica de São João del Rei, MG. In: SBG-MG, Simpósio de Geologia de Minas Gerais, 2, Belo Horizonte, Anais, p. 449-460

Quéméneur J.J.G. and Vidal P. 1989. Primeiras datações radiométricas dos granitos da região de São João del Rei , Minas Gerais. In: SBG-MG, Simpósio de Geologia de Minas Gerais, 5, Belo Horizonte, Anais, p. 50-54

Quéméneur J.J.G., Noce C.M., Garcia D. 1994. Caracterização das suítes granitóides do Arco Mgmático Transamazônico na borda meridional do Cráton do São Francisco, Minas Gerais. In: SBG, Congresso Brasileiro de Geologia, 38, Camboriú, Anais, 1:117-118

Teixeira W. 1985. A evolução geotectônica da porção meridional do Cráton do São Francisco com base em interpretaç̃es geocronológicas. Instituto de Geociências, Unicisco com base em interpretações geocronológicas. Instituto de
versidade de São Paulo, São Paulo, Tese de Doutorado, 207p.

Teixeira W., Cordani U.G., Nutman A.P., Sato K. 1998. Polyphase Archean evolution in the Campo Belo metamorphic complex, Southern São Francisco Craton, Brazil: SHRIMP U-Pb zircon evidence. Journal of South American Earth Sciences, 11:279289

Contribution IGC-121

Received March 1, 2000 Accepted for publication April 22, 2000 